\title{
Article
}

\section{Polish Local Government's Perspective on Revitalisation: A Framework for Future Socially Sustainable Solutions}

\author{
Justyna Przywojska
}

check for

updates

Citation: Przywojska, J. Polish Local Government's Perspective on Revitalisation: A Framework for Future Socially Sustainable Solutions. Energies 2021, 14, 4888. https://doi.org/ $10.3390 /$ en14164888

Academic Editor: Wen-Hsien Tsai

Received: 29 June 2021

Accepted: 4 August 2021

Published: 10 August 2021

Publisher's Note: MDPI stays neutral with regard to jurisdictional claims in published maps and institutional affiliations.

Copyright: (C) 2021 by the author. Licensee MDPI, Basel, Switzerland. This article is an open access article distributed under the terms and conditions of the Creative Commons Attribution (CC BY) license (https:/ / creativecommons.org/licenses/by/ $4.0 /)$.
Department of Labour and Social Policy, University of Łódź, ul. Rewolucji 1905 r. nr 37, 90-214 Łódź, Poland; justyna.przywojska@uni.lodz.pl; Tel.: +48-42-635-52-44

\begin{abstract}
The principal goal of this paper is to investigate the views of local government officials on revitalisation priorities in Polish municipalities. To accomplish this, the perception of revitalisation objectives by local government representatives (who, according to Polish regulations, are responsible for revitalisation planning and carrying it out) was examined. A catalogue of revitalisation objectives, which were assessed by the respondents, was drawn up on the basis of a review of research on the conceptualisation and measurement of sustainable revitalisation and social sustainability at the local level. Exploratory factor analysis was the method used in the study. In total, the list of the examined revitalisation objectives includes 26 objectives related to the following revitalisation dimensions: infrastructure, community, economy, environment, space, co-governance, and inclusion. A survey of the executive bodies of 573 municipalities in Poland revealed a discrepancy between the sustainable approach to revitalisation advocated by the researchers and the perception of revitalisation objectives by the local decision makers. The study demonstrated that decision makers ranked objectives related to the physical dimension of revitalisation and selected objectives related to the social dimension of revitalisation and oriented at counteracting social exclusion by far the highest. The proactive objectives, related to the engagement, mobilisation and integration of the inhabitants, improvement of human capital, stimulation of the local economy and residential satisfaction, were viewed as definitely less important. The challenges facing revitalisation in Poland still fail to be perceived holistically by decision makers, which may hinder the building of strong and sustainable communities.
\end{abstract}

Keywords: sustainable community; social sustainability; urban revitalisation; local authorities; revitalisation priorities; local policy

\section{Introduction}

Today, the idea of sustainable development exerts considerable influence on urban planning and urban development management. The 21st century especially witnessed a meaningful shift in urban policy research towards examining sustainable cities, although the roots of this approach to territorial development processes are much deeper [1-3].

The major concern of local policy is the unsustainable nature of municipalities, as well as the problems resulting from urban sprawl, ageing society, area degradation, pollution or inequalities. These challenges have motivated local governments and researchers to seek appropriate solutions to the integrated and interrelated environmental, economic, and social problems [4]. Many studies have examined sustainable development at the local level and have become sources of diverse development models for cities and their communities, such as: a compact city focused on the urban form [5], a smart city where technology is deployed to resolve complex urban problems, [6-8], an age-friendly city oriented at demographic transition [9-11], a sharing city that relies on the assumptions of the sharing economy [12], or an eco-city, i.e., diverse varieties of an approach focused on environmental assets [13]. These concepts have the following ideas in common: sustainable development and a sustainable and inclusive community. Regardless of differences in the above-listed approaches, at the general level, a sustainable city is understood as a 
system whose social, economic, environmental, and institutional aspects of development are harmoniously integrated with one another [14]. This approach to urban development prevents urban decay in areas heavily affected by multifaceted crisis, usually inhabited by vulnerable and unsustainable communities.

Revitalisation, a process that has greatly evolved over recent decades, is undoubtedly one of the pillars that have shaped the sustainable development of cities. Interventions in urban areas undertaken as part of revitalisation projects have gradually shifted from being place based to becoming people oriented, and today they also consider the assumptions of the above concepts of sustainable urban development. This evolution has become the subject of numerous research works and investigations, and the method used the most frequently in these analyses is chronological classification, which enables finding out about the relationships between changes in urban policy priorities over time and the tools and goals of revitalisation [15]. In this case, chronological thresholds enable the scholar to highlight the changing priorities of regeneration interventions in terms of physical, social, environmental, institutional, and economic objectives. Literature review helps to delineate a clear path along which revitalisation policies evolved in Western European countries from focusing objectives and activities on physical reconstruction to an integrated and comprehensive regeneration of degraded areas carried out in line with the principles of sustainable development, putting special stress on environmental issues and social inclusion [16-18]. A synthetic chronological classification of trends in revitalisation was proposed by, e.g., A. Colantonio and T. Dixon [19], whose approach relied on earlier classifications used by other British authors [16]. They identified six major breakthroughs in revitalisation policy: 1. physical redevelopment (1940s and 1950s); 2. social welfare 1960s; 3. economic prosperity 1970s; 4. property-led regeneration 1980s; 5 . community partnership 1990s; 6. sustainable places 2000s.

The above-presented evolution in revitalisation has made us see it as a sustainable category. Today's approach to revitalisation has done away with former strict divisions between physical redevelopment, social equality and integration, local economic growth, and environmental sustainability. Urban revitalisation is presented as a way to counteract uncontrolled urban sprawl by striving to achieve a compact city model. Undertaken revitalisation interventions aim to rationalise and balance the consumption of resources, minimise the environmental impact of urbanisation, and develop green areas [20]. Sustainable revitalisation is to restore and redevelop residential, commercial or open urban spaces taking care of social and cultural values encapsulated in them by which it can improve economic, physical, and environmental conditions in degraded neighbourhoods [21]. Revitalisation programmes should provide for an integrated process of changes oriented at delivering solutions to often intertwined key problems faced by the city. The process is expected to bring in benefits to those who live in the city now, as well as to the future population, while its key goal is to improve the quality of life of the local community [22]. Understood along these lines, revitalisation has got diverse objectives, e.g., to reduce unemployment, improve the quality of education, invest in human and social capital, renovate buildings and infrastructure, improve the health status of the local community, or prevent crime within the degraded area [21]. All activities are put in place to improve the quality of life of the local community and ensure its social sustainability.

This leads us to a public policy planning paradigm that promotes the holistic and sustainable approach to urban development and solving urban problems and to the public governance paradigm at the local level. Social engagement (participation), collaboration, public-private partnership, and the integration of sectoral policies and programmes under long-term comprehensive urban strategies are important values in this case [23]. The process is supposed to make the complex urban system sustainable and resilient. Many scholars believe that such a governance style to be operational needs leaders-local authorities who are attentive and ready for sustainability transitions [24-27]. Local authorities play out their vital role in educating, mobilising and responding to the public to promote sus- 
tainable development [24]. In the light of this observation, the perception of revitalisation objectives by local policy makers becomes a valid condition for the process.

This paper aims to identify the views of local authorities in Poland on revitalisation priorities in municipalities. Factors that contribute to the diversification of the assessment of revitalisation objectives will also be examined. Findings from the analyses will be used to formulate conclusions and recommendations as to the implementation of socially sustainable revitalisation programmes. Recommendations will also be useful for the programming of revitalisation policy, while the results of studies and key research conclusions can be used for international comparisons. Both the research approach and the catalogue of objectives drafted based on the review of literature on sustainable revitalisation may provide methodological foundations for studies carried out in other countries. The paper has been organised as follows. Section 2 reviews studies focused on sustainable revitalisation and social sustainability. It also discusses the evolution of the approach to revitalisation in Poland. Section 3 outlines the research methodology applied in this study. In addition, it contains basic assumptions and research questions. Next, in Section 4, there are results of research on the perception of revitalisation objectives and factors that differentiate assessments made by local authorities. The same section also contains the results of the factor analysis. Section 5 is a summary of results of conducted analyses and it confronts the major research conclusions with observations of other scholars. Finally, Section 6 is the presentation of major research conclusions.

\section{Literature Review}

\subsection{Socially Sustainable Revitalisation}

In the academic discourse, one can hear voices suggesting that increased interest in sustainable revitalisation calls for an enhanced promotion of socio-economic factors of sustainable development, with social change often triggering the economic change. It is also suggested that revitalisation that has become people-oriented and focuses on social and economic sustainability stands a good chance of achieving measurable benefits in the field of sustainable development [28]. Considerations on urban policy and revitalisation are increasingly more often filled with aspects of social sustainability. At the same time, it is stressed that the concept is far from unambiguous, rather the opposite; it is multidimensional and covers a set of diverse factors that are both tangible and intangible in nature [29-31]. Social sustainability has become a subject in itself, and scholars are striving to come up with a definition and characteristics profile of the notion and propose different methods to measure it. Social sustainability should be viewed as a dynamic concept that changes over time. Literature review has revealed many diverse factors underpinning social sustainability [32]; however, one might easily assume that in urban revitalisation these factors, at the general level, refer to two broad concepts of social equity and sustainability of community [29]. Social equity reflects equity of resources and opportunity to access goods, services, jobs and housing, while community sustainability entails social interaction within a community and community stability, which promotes pride, safety, security, and a sense of place [33]. In the urban context, social equity links with social and environmental exclusion. An equitable community is one that does not exclude or discriminate against any of its members or in any way prevent them from engaging in social life at economic, social, and political levels. Interpreted in this way, social equity embraces traditionally understood mechanisms of the distribution of goods, services, and opportunities (including development opportunities) across a city (distributive justice), as well as equitable social structures and equitable participation mechanisms in public life and in decision-making processes for individuals and social groups [34,35]. On the other hand, sustainability of community refers to collective aspects of social life and covers the following dimensions: social interactions/social networks in the community; participation in social groups and networks in the community; community resilience; pride/sense of place; and safety [29]. Researchers of social sustainability in the urban context [36,37] have listed factors underpinning the major dimensions of social sustainability. 
In particular, social equity covers aspects such as: access to local services and social infrastructure; accessibility of shops, schools, and health care centres; provision of leisure opportunities; accessible public space; public transport; and employment opportunities. Sustainability of community includes the following sub-dimensions: social capital (i.e., social interaction and mutual reciprocity), the sense of community (i.e., psychological attachment) and residential satisfaction (i.e., stability and evaluation of the quality of housing). They include a series of detailed aspects, such as: pride and attachment to the neighbourhood; social interaction within the neighbourhood; safety; perceived quality of the local environment; residential satisfaction; and engagement in the activities of social/citizen groups [37].

Other researchers of spatial planning and management [38] distinguish six key axes of social sustainability at the local level—equity, social inclusion, social cohesion, social capital, safety, and public participation-making clear references to the framework proposed 9 years earlier by British scholars who investigated social sustainability in urban revitalisation and highlighted the importance of the following themes: education and skills; employment; health and safety; housing and environmental health; identity, sense of place and culture; participation, empowerment and access; social capital; social mixing and cohesion; and wellbeing, happiness and the quality of life [39,40]. At the same time, it was noticed that these areas are critical for the sustainable social development of local communities and neighbourhoods, which is why the evaluation of potential direct and indirect impacts of proposed urban revitalisation projects on sustainable social development is fundamental.

Social sustainability is thus supported by activities undertaken in diverse areas from building up the potential and skills development in residents up to counteracting environmental and spatial inequalities. The concept brings together traditional areas and principles of social policy, such as justice and health with aspects of participation, satisfying the needs, social capital, economy, natural environment, and recently with the notion of happiness, wellbeing, and the quality of life [41,42]. Independently of the approach, social sustainability is a way to develop strong and resilient communities capable of coping with: inequality, social injustice, poverty, poor access to health care, segregation, and poor access to resources.

\subsection{Revitalisation Policy in Poland}

In Poland, like in other post-communist countries, territorial development policy founded on social inclusion and local democracy began as late as at the onset of the systemic transformation in the 1990s. The typical features of the previous political system, such as detachment from market economy principles, non-existent land rent, degraded and derelict houses (the so-called "modernisation gap") and residential structures developed at the outskirts of the city led to a subsequent (after the damage inflicted by the WWII) crisis in Polish cities and villages [43,44]. From the early 1990s, together with the progressing globalisation of the economy, cities have experienced growing problems related to social and economic consequences of the collapse of traditional industry. Under such circumstances, solidified urban structures have become obstacles to the development of many functions, including metropolitan ones [44]. At the same time, sub-urbanisation was progressing, driven by economic transformations carried out in the liberal and capitalist spirit. Planning decisions taken in accordance with the newly reanimated private property rights have changed spatial management patterns and created a new pool of plots earmarked for residential functions in suburban zones. As a result, urban sprawl observed in cities of Western Europe for decades has started to affect post-communist cities freed from the straitjacket of central management and control systems [45].

Revitalisation, whose evolution can be seen in the context of three key periods, emerged as a response to the crisis experienced by Polish cities and villages. The first period began with the above-mentioned systemic transformation in the 1990s [46]. The second one 
started when Poland joined the EU in May 2004. The next one, which is currently ongoing, began with the adoption of the breakthrough Act on Revitalisation in 2015 [47].

At the outset, revitalisation in Poland was carried out in a chaotic and haphazard way due to the absence of appropriate legislation, strategies and political guidelines. The organisational and legal support framework for revitalisation was practically non-existent. Moreover, due to the lack of funds, revitalisation efforts at that time were rather scarce [48]. The accession of Poland to the EU significantly improved financial capabilities in the field of revitalisation and promoted its implementation across the country. Unfortunately, local authorities in Polish municipalities saw that mainly as an opportunity to carry out major repairs of buildings, roads and technical infrastructure while social and economic effects of revitalisation remained rather minor. An integrated and sustainable approach to revitalisation in principle did not exist. The deficit of social participation and inter-sectoral collaboration was also visible.

The perception of revitalisation by its principal coordinators, i.e., local authorities, was due to change with the adoption of the Act on Revitalisation in 2015, the first comprehensive legal framework that has put revitalisation efforts in Poland in order. Pursuant to its provisions, revitalisation is understood as a process designed to overcome crises affecting degraded areas conducted in a comprehensive way through integrated efforts undertaken for the benefit of the local community, space, and economy, territorially concentrated and carried out by the stakeholders of revitalisation in line with the municipal revitalisation programme. Dialogue and participation are to be two fundamental values in revitalisation management. According to this piece of legislation, revitalisation may take place in all types of municipalities in Poland, including rural areas. In addition, revitalisation was described as a direction of public intervention in strategic government documents: for rural areas in the Strategy for Rural, Agriculture and Fisheries Development until 2030 [49] and for cities in the National Urban Policy until 2023 [50]. Revitalisation has been given very high priority in the EU financial perspective (2014-2020); it has been mentioned in the Partnership Agreement agreed with the European Commission as one of five of the so-called strategic intervention areas (cities and urban districts in need of revitalisation). Revitalisation projects are co-financed under regional and national operational programmes. Despite such a wide scope of aid, comprehensive, integrated, and balanced revitalisation continues to be something new in Poland, especially that the Act on Revitalisation provides for a transitional period running until 2023, meaning that until 2023 municipalities are not bound with its provisions. Thus, the course of revitalisation in Polish municipalities depends on how revitalisation changes are perceived by local authorities who are its formal leaders.

\section{Materials and Methods}

\subsection{Research Assumptions}

Based on the literature review discussed in the previous sections, a collection of 26 revitalisation objectives is proposed for social, economic, spatial, environmental, infrastructural, and institutional aspects of the process. The set of objectives reflects the principal assumption of the paper according to which sustainable urban regeneration is perceived as a community-based process directed towards achieving the economic, environmental and social well-being of the people through the rejuvenation and revitalisation of the urban fabric. Five dimensions are involved in any sustainable urban regeneration process: inclusive participation by different stakeholders, building communities with character that respect their historical heritages, equitable distribution of benefits and costs to all concerned parties, improving environment and enhancing economic growth [51].

The second assumption relevant for this paper is the conviction that in order to carry out sustainable revitalisation aimed to create a socially sustainable and resilient community, we need local leaders. They can play a major role in promoting basic values, such as altruism, solidarity, generosity, and the civil spirit [52], without which it is hard to put in 
place a good revitalisation change in areas suffering from degradation and decay for many years.

In particular, under the Polish circumstances, the role of local authorities in revitalisation is crucial as, according to the Act on Revitalisation (Art. 3. 1.), the preparation, coordination and creation of conditions for revitalisation, as well as its implementation, are on the task agenda of municipalities. Municipal authorities are therefore responsible for: initiating, planning, organising, coordinating, supporting, controlling and evaluating revitalisation processes $[53,54]$. Political support, including direct engagement of a mayor, is vital for the success of revitalisation due to, inter alia, the need to resolve complex issues and ensuring the collaboration of diverse units. Without such support, the implementation of complex, multifaceted revitalisation programmes is less effective and its outcomes are not so sustainable. The literature review shows that in order to properly fulfil this role, local authorities should see revitalisation in an integrated and holistic way [55]. Therefore, the study examined opinions of village leaders and city mayors on the importance of revitalisation objectives. The research part of the study attempts to answer the following research questions:

RQ1:What is the perception of revitalisation objectives among local executive authorities? RQ2:What factors differentiate the perception of revitalisation objectives by respondents? RQ3:Does the perception of revitalisation objectives suggest that local policy makers have a holistic approach to the process?

\subsection{Data Collection}

Data were collected from a quantitative study conducted in Polish municipalities in 2018. The type of municipality used in this study reflects the current typology of municipalities in Poland, i.e., (a) cities with district status, (b) urban municipalities, (c) urban-rural municipalities and (d) rural municipalities. In 2019, in Poland there were 2478 municipalities, including 66 cities with district status (2.7\% of all municipalities), 236 urban municipalities (9.5\% of all municipalities), 638 urban-rural municipalities, which include within their administrative boundaries both city/town areas, as well as areas outside city limits (25.8\% of all municipalities), and 1537 rural municipalities, which do not have any city/town areas within their administrative boundaries (62.0\% of all municipalities). The invitations and requests to take part in the survey were sent out to all municipalities. Altogether, 1236 municipalities participated (37.2\% of the population of municipalities) in the research. The questionnaire was addressed to the executive bodies (i.e., mayors, heads of villages) and their deputies since they have the greatest influence on the shaping and implementation of revitalisation. The structure of the examined sample is as follows: urban municipalities make up $15 \%$ of the sample, urban-rural municipalities $22.2 \%$, and rural municipalities account for $61.3 \%$ of the sample. Municipalities represent all 16 Polish regions (voivodeships). Among the investigated municipalities, 573 (46\% of the survey sample, $23 \%$ of the entire population of Polish municipalities) were engaged in revitalisation projects, and they are considered in analyses discussed in this paper (Table 1). Responses were given by representatives of executive bodies.

Questionnaire data were analysed using basic descriptive statistics, the Kruskal-Wallis test or the Spearman's rank correlation coefficient (rho). The significance of correlation coefficients was assessed using the $t$-test. These methods were used to identify the relationship between the prioritisation of revitalisation goals and the municipality characteristics (type, affluence).

The study also deployed exploratory factor analysis (EFA) and estimated Cronbach's alpha to group the different objectives into clusters reflecting a similar level of importance, as perceived by respondents. Common variance was found by using the principal component method. The set of variables used in the study was adequate for carrying out factor analysis $\left(\mathrm{KMO}=0.940\right.$, in Bartlett's test of sphericity $\left.\mathrm{p}<0.001^{*}\right)$. The number of factors was identified using the Kaiser criterion. Factor rotation was carried out using the Promax 
method (kappa $=4$ ) because factors were not orthogonal. The calculations were performed in PS IMAGO SPSS 4.0.

Table 1. Study municipalities by municipality type. $(n=573)$.

\begin{tabular}{ccc}
\hline Municipality & Number & \% \\
\hline Urban municipality (UM) & 113 & 19.7 \\
\hline City with a county status (CCS) & 39 & 6.8 \\
\hline Urban-rural municipality (URM) & 184 & 32.1 \\
\hline Rural municipality (RM) & 230 & 40.2 \\
\hline No data & 7 & 1.2 \\
\hline Total & 573 & 100.0 \\
\hline
\end{tabular}

\section{Results}

\subsection{Evaluation of the Importance of Revitalisation Objectives-Respondent Perspective}

Participants of the study representing municipalities that were implementing revitalisation programmes were asked to evaluate the importance of individual revitalisation objectives (on a scale from 1 to 5 , the higher the value of this variable, the bigger the importance of a specific objective). No objective received really high scores that would be close to 5, while relatively high scores (mean exceeding 4) were given to a group of objectives focused, above all, on remedy measures applied in social and technical fields. Improvements in technical infrastructure in the revitalised area scored, relatively, the highest (mean 4.2, three fourth of respondents assessed them as at least 4). However, objectives relating to the social aspects of revitalisation viewed as a method to resolve social issues scored equally high $(\mathrm{M}=4.17, \mathrm{Q} 1=\mathrm{Me}=4)$, together with aid granted to residents threatened with social exclusion and the improvement of social infrastructure $(\mathrm{M}=4.16$, $\mathrm{Q} 1=\mathrm{Me}=4)$. At this point, it is worth stressing that objectives ranking at the top of the evaluation list are obviously compensatory by nature. They can be referred to as reactive objectives designed to offset the deficits of a degraded area, the opposite to the proactive ones oriented at achieving sustainable local development and shaping a community of active and entrepreneurial citizens.

Respondents' opinions equally highly assess measures adopted to improve the aesthetics of the municipality landscape and create common spaces for residents (such as woonerfs, playgrounds, parks). Both objectives are closely interlinked with 'hard' investment projects and relate to the physical aspect of revitalisation. Revitalisation is much less perceived as a way to attract more affluent tenants to newly refurbished apartments. Respondents' assessments suggest that revitalisation is not seen as an opportunity to promote the engagement of local residents in voluntary service (Table 2).

When examining how other objectives were ranked, we can see that local decision makers consistently focus on remedy and offsetting activities (in infrastructure and social sphere), while pro-development measures designed to integrate and mobilise the local community received much lower scores. The minor importance of objectives related to the economic recovery of the area is also rather obvious. This conclusion should raise concerns, as an organised, entrepreneurial, and active community is viewed as a pre-condition for the sustainability of revitalisation transformation.

Importantly, one may observe a consistent approach to different dimensions of revitalisation evidenced in strong correlation between the assessment of individual elements. Respondents who associate revitalisation with improvements in technical infrastructure do not care very much for social objectives (with the exception of the improvement of social infrastructure), while they highly assess other physical aspects of revitalisation: improved quality of the environment, upgrading the technical shape of buildings, and better aesthetics of the municipal landscape (rho correlation indicator ca. $0.34-0.4, \mathrm{p}<0.05$ ). On the other hand, respondents who gave higher scores to supporting residents threatened 
with exclusion or resolving social problems as revitalisation objectives (rho between them $=0.525$ ) appreciated other objectives linked with the social dimension of revitalisation: the development of voluntary services and the improvement of knowledge, skills and abilities of residents.

Table 2. Importance of revitalisation objectives: in the entire population and by type of municipality (on a scale from 1 to 5 ).

\begin{tabular}{|c|c|c|c|c|c|c|c|c|c|c|c|}
\hline \multirow[t]{2}{*}{ Revitalisation Objective } & \multicolumn{6}{|c|}{ Total Population } & \multicolumn{4}{|c|}{$\begin{array}{l}\text { Mean (M) by Type of } \\
\text { Municipality }\end{array}$} & \multirow[t]{2}{*}{ p } \\
\hline & $\mathbf{n}$ & $\mathbf{M}$ & STD & Q1 & Me & Q3 & UM & CCS & URM & $\mathbf{R M}$ & \\
\hline mprove technical infrastructure within the revitalised area & 512 & 4.20 & 0.814 & 4 & 4 & 5 & 4.31 & 3.96 & 4.20 & 4.18 & 0.213 \\
\hline Resolve social problems in the municipality & 516 & 4.17 & 0.893 & 4 & 4 & 5 & 4.40 & 4.57 & 4.10 & 4.06 & $0.001^{*}$ \\
\hline Assist residents threatened with social exclusion & 530 & 4.16 & 0.951 & 4 & 4 & 5 & 4.30 & 4.57 & 4.15 & 4.05 & 0.014 * \\
\hline Improve social infrastructure within the revitalised area & 509 & 4.16 & 0.810 & 4 & 4 & 5 & 4.34 & 4.21 & 4.18 & 4.06 & 0.040 * \\
\hline Improve the aesthetics of municipality landscape & 504 & 4.15 & 0.737 & 4 & 4 & 5 & 4.20 & 4.17 & 4.18 & 4.11 & 0.716 \\
\hline $\begin{array}{l}\text { Develop public spaces for residents, such as woonerfs, } \\
\text { playgrounds, or parks }\end{array}$ & 510 & 4.13 & 0.853 & 4 & 4 & 5 & 4.12 & 4.31 & 4.17 & 4.06 & 0.370 \\
\hline Repair roads, pavements, and lighting & 533 & 4.00 & 1.096 & 3 & 4 & 5 & 3.72 & 3.37 & 3.97 & 4.21 & $<0.001^{*}$ \\
\hline Improve safet & 501 & 3.97 & 0.854 & 4 & 4 & 5 & 4.10 & 4.07 & 4.05 & 3.82 & $0.014^{*}$ \\
\hline Improve & 506 & 3.96 & 0.844 & 4 & 4 & 5 & 4.00 & 3.97 & 3.98 & 3.92 & 0.871 \\
\hline Improve infras & 507 & 3.94 & 0.848 & 3 & 4 & 5 & 3.97 & 3.97 & 4.06 & 3.83 & 0.075 \\
\hline $\begin{array}{r}\text { Encourage residents to tak } \\
\text { neigh }\end{array}$ & 496 & 3.90 & 0.916 & 3 & 4 & 5 & 3.99 & 4.34 & 3.89 & 3.80 & $0.002 *$ \\
\hline Improve environmental & 491 & 3.86 & 0.830 & 3 & 4 & 4 & 3.95 & 3.89 & 3.91 & 3.79 & 0.386 \\
\hline Foster communit & 498 & 3.81 & 0.928 & 3 & 4 & 4 & 3.97 & 4.30 & 3.71 & 3.75 & $0.003^{*}$ \\
\hline ncrease the populatio & 485 & 3.81 & 0.948 & 3 & 4 & 4 & 3.86 & 4.00 & 3.85 & 3.74 & 0.355 \\
\hline $\begin{array}{r}\text { Ensure equal access to } r \\
\text { groups of } r\end{array}$ & 492 & 3.71 & 0.912 & 3 & 4 & 4 & 3.89 & 3.97 & 3.69 & 3.58 & 0.017 \\
\hline Improve the quality of educatio & 495 & 3.70 & 0.958 & 3 & 4 & 4 & 3.67 & 3.57 & 3.77 & 3.68 & 0.687 \\
\hline Improve knowledge, skills, & 492 & 3.64 & 0.936 & 3 & 4 & 4 & 3.61 & 3.97 & 3.65 & 3.58 & 0.158 \\
\hline Attract new, large & 488 & 3.62 & 1.071 & 3 & 4 & 4 & 3.57 & 3.60 & 3.78 & 3.53 & 0.172 \\
\hline Increase the 1 & 483 & 3.60 & 0.942 & 3 & 4 & 4 & 3.61 & 3.76 & 3.67 & 3.52 & 0.390 \\
\hline Integrate the activitie & 487 & 3.57 & 0.890 & 3 & 4 & 4 & 3.63 & 4.07 & 3.58 & 3.45 & $<0.001^{*}$ \\
\hline Improve health status of residents & 481 & 3.56 & 0.938 & 3 & 4 & 4 & 3.46 & 3.50 & 3.70 & 3.50 & 0.100 \\
\hline $\begin{array}{l}\text { Develop more higher quality green areas in the } \\
\text { municipality }\end{array}$ & 487 & 3.54 & 885 & 3 & 4 & 4 & 3.67 & 3.72 & 3.69 & 3.33 & $<0.001 *$ \\
\hline Build local partn & 491 & 3.52 & 0.924 & 3 & 4 & 4 & 3.67 & 4.03 & 3.52 & 3.37 & $0.001^{*}$ \\
\hline Support and promote local craftsmen and products & 483 & 3.48 & 0.960 & 3 & 4 & 4 & 3.44 & 3.64 & 3.58 & 3.38 & 0.199 \\
\hline Increase residents' engagement in municipal governance & 480 & 3.46 & 0.929 & 3 & 4 & 4 & 3.62 & 3.63 & 3.49 & 3.33 & 0.056 \\
\hline Improve the performa & 481 & 3.30 & 1.030 & 3 & 3 & 4 & 3.33 & 3.43 & 3.37 & 3.21 & 0.410 \\
\hline Promote voluntary service among residents & 481 & 3.21 & 0.930 & 3 & 3 & 4 & 3.27 & 3.48 & 3.32 & 3.07 & $0.023^{*}$ \\
\hline Inflow of new, affluent tenants to refurbished apartments & 478 & 2.83 & 1.098 & 2 & 3 & 4 & 2.95 & 2.89 & 3.00 & 2.64 & $0.015^{*}$ \\
\hline
\end{tabular}

$\mathrm{p}$-probability in the F-test of variances or in Welch's test (after having eliminated the missing answers); ${ }^{*}$-statistically significant differences $(\alpha=0,05)$. Type of municipality: UM—urban, CCS—cities with a county status, URM—urban-rural, RM—rural; Q1—quartile 1, Q3-quartile 3, Me - median, STD—standard deviation, n-no. of municipalities that took part in the assessment exercise; groups with the highest average score for individual objectives are marked in grey. Source: author's own research.

\subsection{Factors Differentiating the Perception of Revitalisation Objectives}

One needs to bear in mind that, in Poland, the perception of revitalisation objectives depends on the type of municipality that a respondent represents. More urbanised areas are more oriented towards a social approach to revitalisation. This can be explained by a bigger experience of cities in the implementation of revitalisation activities and in using consulting services under government programmes, such as the "Social Revitalisation" programme implemented over the period 2008-2015, financed from the European Social Fund and designed to work out a Model Standard of Active Integration, a method applied to work with the local community from the revitalised area.

The importance of the first objective (improve technical infrastructure) is slightly less appreciated in bigger cities (cities with a county status), which have a much stronger focus on reactive social objectives: resolving social problems and giving support to residents 
threatened with social exclusion. At the same time, cities with a county status gave higher scores to proactive social objectives, connected with the development of an inclusive, collaborative, and active community than other types of municipalities (especially rural ones). Respondents from cities with a county status gave higher scores to the following objectives: encourage residents to take care of themselves and their neighbourhood; foster community bonds between residents; integrate the activities of different local institutions; build local partnerships; increase residents' engagement in municipal governance; and promote voluntary service among the residents. Focusing decision makers' attention on the above objectives is more than desirable in the social sustainability concept, as they empower residents and trigger local collaboration. Compared to other municipalities, cities with a county status ranked the importance of revitalisation for ensuring equal opportunities of access to municipal resources to different groups of residents and users and for providing more green areas of improved quality in the municipality the highest. In turn, respondents from rural municipalities scored typical interim activities, such as repairs of roads, pavements, and lighting, much higher.

The above observations are confirmed by the examination of the impact of employment in the office on the perception of the importance of revitalisation objectives. The higher the employment (a derivative of municipality size and type), the bigger (on average) the importance of social objectives. On the other hand, infrastructural objectives are ranked the highest by respondents representing municipalities where the employment in municipal office is the lowest (the smallest rural municipalities).

Interestingly, a statistically significant relationship emerges between the years spent by the respondents in NGOs and the perception of social objectives. The more years served in NGOs, the higher the average assessment of revitalisation as an effort serving to resolve social issues in the municipality (rho $=164, \mathrm{p}=0.038^{*}$ ) and develop the voluntary service (rho $=0.187, \mathrm{p}=0.021^{*}$ ). In turn, respondents with more experience in running their own businesses ranked the importance of revitalisation as a way to attract new, large companies to invest in the municipality (rho $=0.110, \mathrm{p}=0.049^{*}$ ) and improve the quality of the environment within the revitalised area $(\mathrm{rho}=0.130, \mathrm{p}=0.019 *)$, on average, higher. This leads to the conclusion that the activity of the mayor outside the local government sector influences his perception of revitalisation priorities.

\subsection{Exploratory Factor Analysis: Importance of Revitalisation Objectives}

As a next step, exploratory factor analysis (EFA) and estimate Cronbach's alpha were deployed to group the different objectives (described in the previous section: Table 2) into clusters reflecting a similar level of importance to that perceived by respondents. Common variance was found by using the principal component method. The set of variables used in the study was adequate for carrying out factor analysis (KMO $=0.940$, in Bartlett's test of sphericity $\left.\mathrm{p}<0.001^{*}\right)$. Exploratory factor analysis allowed one to identify five factorsbundles of revitalisation objectives (in brackets, factor loadings are given for individual factors):

1. Factor 1 (F1) - Social inclusion, human and social capital (alfa-Cronbach coefficient 0.889):

- $\quad$ Support to residents threatened with social exclusion (0.906);

- Improve residents' knowledge, skills, and abilities (0.732);

- $\quad$ Foster community bonds between residents (0.719);

- Resolve social issues in the municipality (0.669);

- $\quad$ Build local partnerships (0.525);

- Integrate activities of different local institutions (0.511).

2. Factor 2 (F2) - Local economic development (alfa-Cronbach coefficient 0.804):

- Inflow of new, large companies to the municipality (0.806);

- Improve the performance of public transport (0.654);

- Improve the health status of residents (0.653); 
- Inflow of new affluent tenants to refurbished apartments (0.635);

- Support and promotion for local craftsmen and products $(0.601)$;

- Repair roads, pavements, and lighting $(0.566 ; 0.412$ for Factor 4$)$;

- Increase the number of businesses within the revitalised area (0.559).

3. Factor 3 (F3)-Self-determination and residential satisfaction (alfa-Cronbach coefficient 0.875):

- Increase residents' engagement in municipal governance (0.801);

- Ensure equal access opportunities to municipal resources for different groups of residents and users (0.748);

- Promote voluntary service among residents (0.664);

- Encourage residents to take care of themselves (0.648);

- Increase residents' sense of happiness (0.512);

- Improve safety within the revitalised area (0.512);

- Improve the quality of education within the revitalised area (0.454).

4. Factor 4 (F4)-Infrastructure (alfa-Cronbach coefficient 0.793):

- Improve technical infrastructure within revitalised area (0.776);

- Improve the aesthetics of the municipal landscape (0.722);

- Improve the technical shape of buildings (0.652);

- Improve social infrastructure within the revitalised area (0.560);

- Improve environmental quality within the revitalised area (0.454).

5. Factor 5 (F5) - Shaping public space for residents (alfa-Cronbach coefficient 0.770):

- Develop more higher quality green areas in municipality (0.718);

- Develop public spaces for residents (woonerfs, playgrounds, parks) (0.673);

- Improve infrastructure for leisure-time activities (0.644).

Each indicator (except the last one) consists of a similar number of components. Importantly, the sequence of factors tells us how relevant they are for the assessment of the importance of revitalisation objectives. The first and the most important factor explains $40 \%$ of the variance of the latent variable, which in this case could be described as the importance of revitalisation objectives. Thus, one may conclude that the factor F1 "Social inclusion, social and human capital" is the most important for the general assessment of revitalisation (which, in accordance with the applied methodology, does not mean, however, that respondents score the objectives that underpin it the highest). Within this group of objectives, the assessment of revitalisation as a reactive method offering support to residents threatened with social exclusion is the most important (factor loading, indicating the degree of correlation with the factor F1, for this variable is the highest, significantly higher than for other components in this group). Next in the importance ranking come activities designed to build up the human capital of residents and foster community bonds between them. Another group of revitalisation objectives relevant for their overall assessment covers economic objectives (F2- "Local economic development") including the inflow of new, large companies to the municipality. In this group, attention should be paid to the 'repair of roads, pavements, and lighting' as a component closely linked with Factor 4-infrastructure. Nevertheless, the construction of road infrastructure is also important for economic development, which may act as a powerful incentive to move one's business to the municipality. This explains why the indicator has been included in this very group. The presence of 'improvement of residents' health status' in this group is also intriguing. Other scholars clearly suggest there is a relationship between the health status and professional activity or the absence thereof [56]. Health is also part of human capital, which determines the economic standing of an individual. The impact of urban revitalisation on residents' health is also examined $[57,58]$.

Next comes the (F3) "Self-determination and residential satisfaction" factor connected with the mobilisation of residents and ensuring good living conditions. In the light of results obtained in this area, the most important (but does not necessarily receiving the highest scores) is the increase in residents' engagement in municipal governance and ensuring 
equal opportunities in access to municipal resources to different groups of residents and users.

The fourth position (in the general assessment framework of revitalisation objectives) is occupied by infrastructural objectives (F4), including the improvement of technical infrastructure within the revitalised area and improved aesthetics of the municipal landscape. The last group brings together objectives relating to the development of public space for residents (F5).

Each indicator is highly reliable (alfa-Cronbach coefficient above 0.7), which means five synthetic indicators can be identified to further provide a summary assessment of the importance of revitalisation objectives in these five groups. They were calculated as an arithmetic mean from partial variables; therefore, each of the indicators can take values from the range $[0,1]$, and the higher the value, the higher the ranking of the importance of a given group of revitalisation objectives. The distribution of these indicators within the sample is shown in Figure 1.

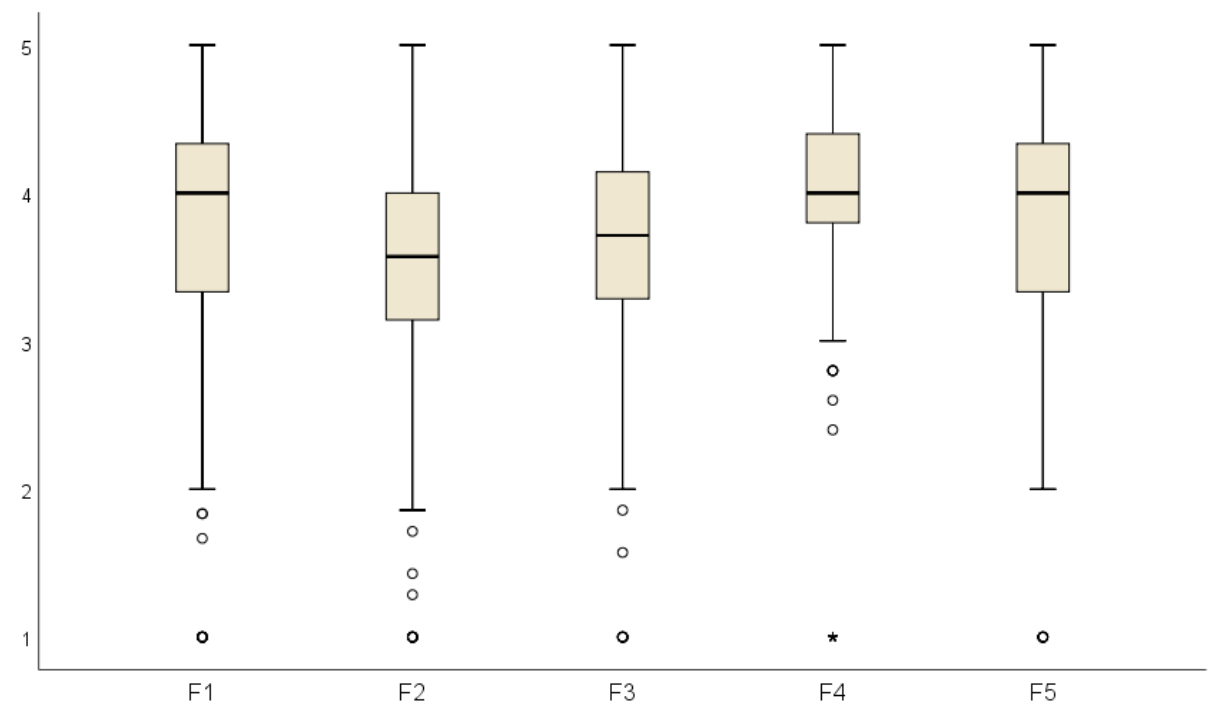

Figure 1. Synthetic assessment of the importance of revitalisation objectives, Option 2. Source: author's own research.

The analysis of importance of individual revitalisation objectives as assessed by representatives of municipalities (Figure 1, Table 3) allows us to conclude that the highest and very similar score was given to three objectives: social one connected with inclusion, social and human capital (F1); infrastructural (F4); and relating to the development of public space for municipal residents (F5). The median is slightly lower for objectives connected with self-determination and residential satisfaction (F3) and even lower for economic objectives (F2) (the value for quartiles Q1 and Q 3 is also lower). It is worth stressing a significant homogeneity in the assessment of the importance of infrastructural objectives (F4).

Some differences have been detected across different types of municipalities. In cities with a county status, the importance of social objectives from Group 1 is rated significantly higher-mean score 4.24 compared to even 3.69 in rural municipalities. On the other hand, from the viewpoint of objectives included in Group 5, rural municipalities where the assessment of revitalisation as a way to develop public space is the lowest (3.7) stand out negatively against other types of municipalities having the score levels close to 4 . For other revitalisation objectives, differences are not statistically significant (Table 3). 
Table 3. Synthetic assessment of the importance of revitalisation objectives, for the total population and by types of municipalities (on a scale from 1 to 5 ).

\begin{tabular}{|c|c|c|c|c|c|c|c|c|c|c|c|}
\hline Indicator & $\mathbf{n}$ & Mean & STD & Q1 & Me & Q3 & $\begin{array}{c}\text { Urban } \\
\text { Municipality }\end{array}$ & $\begin{array}{l}\text { City with } \\
\text { County Status }\end{array}$ & $\begin{array}{l}\text { Urban-Rural } \\
\text { Municipality }\end{array}$ & $\begin{array}{c}\text { Rural } \\
\text { Municipality }\end{array}$ & p \\
\hline Social inclusion, human and social capital & 462 & 3.80 & 0.736 & 3.33 & 4.00 & 4.33 & 3.95 & 4.24 & 3.76 & 3.69 & $<0.001 *$ \\
\hline Local economic development & 455 & 3.49 & 0.724 & 3.14 & 3.57 & 4.00 & 3.48 & 3.51 & 3.58 & 3.42 & 0.220 \\
\hline $\begin{array}{l}\text { Self-determination and residential } \\
\text { satisfaction }\end{array}$ & 459 & 3.64 & 0.687 & 3.29 & 3.71 & 4.00 & 3.73 & 3.80 & 3.68 & 3.54 & 0.065 \\
\hline Infrastructure & 466 & 4.05 & 0.587 & 3.80 & 4.00 & 4.40 & 4.13 & 4.02 & 4.07 & 3.99 & 0.286 \\
\hline Shaping public space for residents & 477 & 3.85 & 0.712 & 3.33 & 4.00 & 4.33 & 3.92 & 4.00 & 3.95 & 3.70 & $0.002 *$ \\
\hline
\end{tabular}

p-probability in the F-test of analysis of variances (after having eliminated the missing answers); ${ }^{*}$-statistically significant differences $(\alpha=0,05)$. Q1-quartile 1, Q3-quartile 3, Me-median, STD-standard deviation, $\mathrm{n}$-no. of municipalities which took part in the assessment exercise. Source: author's own research.

Individual dimensions of revitalisation objectives correlate positively with one another and therefore a higher rating of particular factors (importance of revitalisation objectives) is accompanied by a higher rating of other factors (Table 4). The strongest relationship can be observed between the assessment of both social objectives: the higher the rating of the role of revitalisation as a method to accomplish objectives concerning the social inclusion and human and social capital development, the higher the average assessment of the importance of revitalisation for self-determination and residential satisfaction (and the reverse). Notably, the last issue is strongly linked with seeing revitalisation as a way to achieve economic objectives; here, there is also a strong positive correlation (rho $=0.557$ ).

Table 4. Relationships between synthetic assessment of the importance of individual revitalisation objectives.

\begin{tabular}{|c|c|c|c|c|c|c|}
\hline \multicolumn{2}{|c|}{ Item } & Factor 1 & Factor 2 & Factor 3 & Factor 4 & Factor 5 \\
\hline \multirow{2}{*}{ Factor 1} & rho & 1 & 0.402 & 0.667 & 0.283 & 0.435 \\
\hline & $\mathrm{p}$ & & $<0.001 *$ & $<0.001^{*}$ & $<0.001^{*}$ & $<0.001$ * \\
\hline \multirow[b]{2}{*}{ Factor 2} & rho & 0.402 & 1 & 0.557 & 0.418 & 0.386 \\
\hline & $\mathrm{p}$ & $<0.001^{*}$ & & $<0.001^{*}$ & $<0.001^{*}$ & $<0.001^{*}$ \\
\hline \multirow{2}{*}{ Factor 3} & rho & 0.667 & 0.557 & 1 & 0.425 & 0.471 \\
\hline & $p$ & $<0.001^{*}$ & $<0.001^{*}$ & & $<0.001^{*}$ & $<0.001^{*}$ \\
\hline \multirow{2}{*}{ Factor 4} & rho & 0.283 & 0.418 & 0.425 & 1 & 0.369 \\
\hline & $\mathrm{p}$ & $<0.001^{*}$ & $<0.001^{*}$ & $<0.001^{*}$ & & $<0.001^{*}$ \\
\hline \multirow{2}{*}{ Factor 5} & rho & 0.435 & 0.386 & 0.471 & 0.369 & 1 \\
\hline & $\mathrm{p}$ & $<0.001^{*}$ & $<0.001^{*}$ & $<0.001$ * & $<0.001^{*}$ & \\
\hline
\end{tabular}

rho-Spearman correlation rank coefficient, $\mathrm{p}$-probability in $t$-test of correlation coefficient significance, ${ }^{*}$-statistically significant correlation $(\alpha=0.05)$. Source: author's own research.

The results of the factor analysis correlate with the assumptions of sustainable revitalisation and social sustainability concepts and coincide with views presented by other authors referred to in this paper. On the other hand, the evaluation of the importance of revitalisation objectives by decision makers does not manifest a sustainable approach to revitalisation. Physical (infrastructural and spatial) perspective prevails. Moreover, the role of social objectives is highly appreciated, although in the part limited to reactive actions, focused on providing solutions to social problems and offering support to residents threatened with social exclusion. It means that the social dimension of revitalisation promotes objectives subordinated to social justice categories while at the same time the sustainability of community remains underappreciated.

\section{Discussion}

The postulate of sustainable revitalisation oriented at improved quality of life and social sustainability clearly resonates within the academic discourse [59-62]. Some scholars investigating into urban policy issues stress that the debate developing around sustainability has advanced from ecology and environmental issues to social and economic ones 
and has clearly acquired an urban dimension [63]. However, the practical implementation of the suggested approaches and solutions adopted within revitalisation processes turns out to be rather problematic. That is because revitalisation stakeholders have so far underestimated the importance of certain aspects of sustainable development which emerge from interactions between social and economic issues [64]. Little attention paid to wider economic effects of urban revitalisation in the past may be, perhaps, symptomatic of the overall lack of political sensitivity to local social problems. In post-communist countries, the social dimension emerged rather slowly [23]. Findings of studies discussed in the previous section seem to partly substantiate these observations.

Factor analysis helped in distinguishing five bundles of objectives (factors), amongst which the factor (F1) 'Social inclusion, human and social capital' is the most important for revitalisation. It covers diverse social objectives designed to ensure social integration, counteracting social exclusion, and promoting collaboration between local actors. By referring to the earlier discussed social sustainability concept, one may observe that the factor integrates categories, such as the social justice and sustainability of community. At the same time, this factor is the most important for revitalisation. This observation confirms views of other scholars who highlight the importance of social sustainability in revitalisation (discussed in Section 2.1).

The second factor (F2) is 'Local economic development', bringing together objectives connected with the expansion of the local economic base and infrastructure necessary for business operations, increasing local demand and improving the health status of residents. This factor is also relevant for revitalisation. In the economic dimension, revitalisation is a rather complex phenomenon that covers objectives focused on the regeneration of material resources, restoring the health of human resources, increasing local demand by attracting new, more affluent residents, as well as pursuing operations on the supply side consisting in the increasing of the number of businesses and offering support to local craftsmen. Economic revitalisation has also been perceived in a similar way by other scholars [65]. One may be surprised with the presence of the 'Improve residents' health status' objective in this group; however, studies have confirmed both the relationship between the deprivation of urban areas and the health status of residents of degraded areas [66], as well as between the health status and active participation in the labour market [56].

Such a structure of economic objectives agrees with the contemporary understanding of local economic development whose priority is to build up the economic potential of the local community to secure a better economic future for it and to improve the quality of life of all residents [67]. A similar collection of economic development objectives is also suggested by researchers who examine inclusive growth, emphasise the need to develop inclusive economic structures, and expand the economic base taking care of the quality of local social services and providing physical conditions for business development through the expansion of technical infrastructure and the development of transport [68].

The factor F3-'Self-determination and residential satisfaction' — covering objectives linked with improving the quality of local services, social engagement, and the sense of happiness, ranked third in importance for revitalisation. Even though its importance for revitalisation is smaller, it embraces objectives linked with the concept of empowerment and the social engagement of local communities [69] that complement the first and most important factor (F1).

Infrastructural objectives and objectives related to the development of public spaces clearly seem to be the least important in revitalisation. This observation is especially relevant as it subscribes to the approach described in the Act on Revitalisation binding in Poland. Pursuant to the Act, a degraded area to be covered by revitalisation effort must, above all, focus negative social occurrences accompanied by at least one negative economic, environmental, spatial-functional, or technical phenomenon. It is an attempt to direct revitalisation towards improving the quality of life of residents. In this case, solutions in the field of infrastructure, transport or construction are supposed to play an ancillary role. 
The results of the factor analysis confirm that sustainable revitalisation that leads to the development of a strong, economically competitive, socially cohesive and sustainable community is welcome. Nevertheless, the evaluation of the importance of revitalisation objectives by decision makers in Polish municipalities largely deviates from these assumptions. Respondents ranked the importance of the improvement of technical infrastructure within the revitalised area the highest. High scores were also given to objectives pertaining to the reconstruction of physical structures: improve social infrastructure within the revitalised area; improve the aesthetics of the municipal landscape; develop public space for residents, such as woonerfs, playgrounds, parks; repair roads, pavements, and lighting. Studies carried out by other Polish researchers also suggest a prevalence of objectives proposing major repairs that could improve the image of a municipality and its spatial order [70-73].

The following equalisation-oriented social objectives were evaluated equally highly: resolving social issues in municipality and offering support to residents threatened with social exclusion. This may be seen as a minor step towards perceiving revitalisation as a socially sustainable category. Similar findings result from studies conducted by the Statistics Poland [GUS] [74]. The structure of measures planned in revitalisation programmes binding in 2017 was dominated by undertakings from the social area (ca. 36\%), i.e., those carried out, in particular, in the field of unemployment, poverty, crime, low quality of education or social capital, as well as insufficient engagement in public and cultural life. Other numerous interventions targeted the following areas: (a) spatial and functional (26-28\%), where proposed activities addressed the following challenges: shortcomings in technical and social infrastructure, lack of access to basic services or their low quality, solutions proposed in urban planning mismatching the evolving functions of the areas, low quality of local public transport services, and insufficient or low quality of public space; (b) technical (22\%) focused mainly on activities within a degraded neighbourhood targeting technical shape of building structures, including residential ones, and the absence of technical solutions that would facilitate effective use of buildings, especially when it comes to energy savings and environmental protection. Unfortunately, GUS does not provide data on the share of economic undertakings in the revitalisation of Polish municipalities. This can be considered symptomatic, as in my studies economic objectives of revitalisation can also be found among the lowest-ranked objectives by respondents. This research finding is confirmed in works of other scholars. There is a general belief that economic measures are included in revitalisation programmes just to comply with the requirement of ensuring an integrated approach to revitalisation and increase chances to win EU funds while their practical application is very limited [73]. Studies conducted by the Institute of Urban and Regional Development revealed that among the 5521 revitalisation projects that they examined, the majority proposed measures that impact the social sphere $(69.5 \%)$, while actions that impact environmental aspects were scarce $(21 \%)$, with economic measures featuring only slightly more frequently (25\%) [75]. Obtained results also inform that local decision makers fail to realise how important it is to support local craftsmen and promote local products in the course of revitalisation. Similar observations have also been made by other scholars [64]. From the perspective of economic growth, current approaches to revitalisation focus on attracting new businesses and creating new job opportunities, which often replace local renowned firms that they have squeezed out from the market.

A subsequent evaluation report for the system of revitalisation in Poland suggests that until 2018 Polish municipalities planned over 2000 undertakings in the economic sphere, out of which only $16 \%$ were put in place [76]. Urban municipalities stand out with their activities in the economic dimension, especially cities with the county status where activities that stimulate local economy take place. In rural municipalities, in turn, practically no economic activities are exercised. The results of my studies also indicate that respondents from small rural municipalities focus, above all, on repair and modernisation efforts and do not appreciate the importance of steps aimed at achieving economic recovery. In this case, the reason may be infrastructure deficits in some rural municipalities in Poland. 
Compared to cities, Polish villages have relatively little developed technical, cultural, tourist, sports, and leisure infrastructure [77-79].

The above-presented conclusions from studies conducted in Poland at national level are largely reflected in regional studies carried out a little earlier across the country. The essential difference lies in the fact that regional studies focused on effects of revitalisation accomplished before 2015, i.e., before the Act on Revitalisation entered into force. In studies conducted in the Opolskie region [72], representatives of local government were asked to identify effects of revitalisation efforts undertaken in their municipalities. Spatial effects (understood by scholars as technical restoration measures: modernisation, renovation, adapting buildings to perform new functions) clearly prevailed in their answers (36.5\%), followed by lower-ranked social effects $(22.5 \%)$. Further, in the ranking of effects there were infrastructural $(16.3 \%)$, environmental $(14.0 \%)$ and economic $(10.7 \%)$ outcomes. The dominant importance of spatial effects of revitalisation, with moderate importance of social effects and a minor role played by economic effects, is also indicated by researchers of revitalisation in the region of Wielkopolska [47]; however, their studies cover a time perspective that is so long (1999-2015) that one cannot consider them reliable under current circumstances in Poland. Nevertheless, they undoubtedly confirm the findings of all the above-quoted analyses.

Respondents' feedback also reveals little attention being paid to promote engagement, collaboration, and partnership under revitalisation projects. Objectives such as building local partnerships and enhancing residents' engagement in municipal governance were rated low. No pressure exerted to change the local governance paradigm to co-governance may significantly impede the transition to a sustainable community. Other studies conducted in Poland in recent years also inform about the poor effectiveness of social participation processes within the framework of urban regeneration programmes [80-82]. Social participation, so strongly accentuated and currently required by binding strategic documents on revitalisation, in practice means a real challenge to cities, which until now usually deployed it within a very limited scope [83].

The presented research results are consistent with the general conclusions of other researchers in Poland [71,73,84-88]. The major weaknesses of the current approach to revitalisation processes include: concentration on the renovation of physical infrastructure, fragmentation of activities and their superficial connection to the economic and social objectives of revitalisation, lack of social participation and the closing of the circle of a fixed, limited set of tasks for local authorities. A consequence of the above-mentioned failures may be the disintegration of revitalisation projects and the impossibility of achieving the most important objective of revitalisation-a holistic, integrated improvement in the condition of the area and its community on the basis of a newly devised concept of sustainable development that makes use of the heritage and potentials of the revitalised area.

\section{Conclusions}

Conducted studies have confirmed the significant importance of social sustainability in revitalisation, providing, at the same time, guidelines for planners, coordinators, and executors of revitalisation projects. The results of the factor analysis provide further evidence. The social factor (F1), combining objectives related to the social justice and sustainability of a community, is crucial for revitalisation. The next factor important for revitalisation is (F2) "Local economic development", which clearly confirms the need, postulated by other authors, to appreciate the role of the social and economic dimension of revitalisation, the links between them and their relevance for sustainable urban development. The results of the factor analysis also clearly suggest a lower importance of the infrastructural factor, which coincides with the sustainable revitalisation approach, in which material aspects serve to improve the quality of life within the revitalised area. The refurbishment of buildings and the expansion of infrastructure become a method of achieving a much broader goal: to create strong, entrepreneurial, sustainable, and resilient local communities. 
Unfortunately, feedback given by Polish decision makers does not reflect this approach. Technical objectives related to the expansion of, and major repairs to, infrastructure were ranked the highest. On a positive note, social objectives are highly ranked; however, this is only true only when they are limited to reactive objectives of local social policy, which are usually executed within the context of the local welfare system. Proactive objectives, such as collaboration, mobilisation, integration, participation, and entrepreneurship, ranked much lower. In addition, economic revitalisation and local collaboration receive little interest. When analysing respondents' answers, we may assume that local decision makers continue viewing revitalisation as a method to accomplish their typical obligatory tasks using external funds. Obviously, supplementing local deficits in infrastructure and improving the aesthetics of the municipal landscape are valid objectives of revitalisation change. Similarly important are objectives aimed to resolve social problems and offer support to residents threatened with social exclusion. Nevertheless, such orientation of revitalisation does not suffice to effectively respond to a comprehensive and multifaceted local crisis, especially when the objective is to create a resilient and sustainable community. Material objectives, the most important in respondent opinions, may of course improve the attractiveness of space and indirectly contribute to, e.g., stimulating the local economy or increasing the sense of safety. However, they need to be accompanied by conditions, not only technical, that promote the engagement, activism, care, and responsibility for the neighbourhood amongst revitalisation stakeholders. The implementation of socially sustainable revitalisation should also be seen as a living laboratory for solutions that can be applied on a wider scale, across the municipality. It helps to recognise and test new methods of promoting resident engagement, stimulating the economy, or building up links between urban policy stakeholders within the revitalised area. In this way, revitalisation becomes a space for experimenting and developing new solutions to the already existing social or economic problems.

Funding: This research received no external funding.

Institutional Review Board Statement: Not applicable.

Informed Consent Statement: Not applicable.

Data Availability Statement: Not applicable.

Acknowledgments: The author thanks everyone who provided constructive advice that helped to improve this paper.

Conflicts of Interest: The author has declared that no competing interests exist.

\section{References}

1. Hassan, A.M.; Lee, H. The paradox of the sustainable city: Definitions and examples. Environ. Dev. Sustain. 2015, 17, 1267-1285. [CrossRef]

2. Skrede, J.; Berg, S.K. Cultural Heritage and Sustainable Development: The Case of Urban Densification. Hist. Environ. Policy Pract. 2019, 10, 83-102. [CrossRef]

3. Asekomeh, A.; Gershon, O.; Azubuike, S.I. Optimally Clocking the Low Carbon Energy Mile to Achieve the Sustainable Development Goals: Evidence from Dundee's Electric Vehicle Strategy. Energies 2021, 14, 842. [CrossRef]

4. Przywojska, J.; Podgórniak-Krzykacz, A. A comprehensive approach: Inclusive, smart and green urban development. Probl. Ekorozwoju 2020, 15, 149-160. [CrossRef]

5. Næss, P.; Saglie, I.L.; Richardson, T. Urban sustainability: Is densification sufficient? Eur. Plan. Stud. 2020, 28, 146-165. [CrossRef]

6. Fujinawa, Y.; Kouda, Y.; Noda, R. The Resilient Smart City (an Proposal). Selected Papers from TIEMS Annual Conference in Niigata. J. Dis. Res. 2015, 10, 319-325. [CrossRef]

7. Meerow, S.; Newell, J.P.; Stults, M. Defining urban resilience: A review. Landsc. Urban Plan. 2016, 147, 38-49. [CrossRef]

8. Mehmood, A. Of resilient places: Planning for urban resilience. Eur. Plan. Stud. 2016, 24, 407-419. [CrossRef]

9. Steels, S. Key characteristics of age-friendly cities and communities: A review. Cities 2015, 47, 45-52. [CrossRef]

10. Buffel, T.; Phillipson, C.; Rémillard-Boilard, S. Age-Friendly Cities and Communities: New Directions for Research and Policy. In Encyclopedia of Gerontology and Population Aging; Springer International Publishing: Berlin/Heidelberg, Germany, 2019; pp. 1-10. 
11. Podgórniak-Krzykacz, A.; Przywojska, J.; Wiktorowicz, J. Smart and age-friendly communities in Poland. An analysis of institutional and individual conditions for a new concept of smart development of ageing communities. Energies 2020, 13, 2268. [CrossRef]

12. Salvia, G.; Morello, E.; Arcidiacono, A. Sharing Cities Shaping Cities. Urban Sci. 2019, 3, 23. [CrossRef]

13. Antuña-Rozado, C.; García-Navarro, J.; Mariño-Drews, J. Facilitation Processes and Skills Supporting EcoCity Development. Energies 2018, 11, 777. [CrossRef]

14. Robertson, M. Sustainable Cities. Local Solutions in the Global South; International Development Research Centre: London, UK, 2012

15. Marra, G.; Marietta, C.; Tabasso, M.; Eynard, E.; Melis, G. From urban renewal to urban regeneration: Classification criteria for urban interventions. Turin 1995-2015: Evolution of planning tools and approaches. J. Urban Regen. Renew. 2016, 7, $188-197$.

16. Roberts, P.; Sykes, H. Urban Regeneration: A Handbook, 1st ed.; SAGE Publications Ltd.: Thousand Oaks, CA, USA, 2000.

17. Hall, T. Urban Geography, 3rd ed.; Routledge: New York, NY, USA, 2005.

18. Raco, M. Building Sustainable Communities: Spatial Policy and Labour Mobility in Post-War Britain; Bristol University Press: Bristol, UK; Policy Press: Bristol, UK, 2007.

19. Colantonio, A.; Dixon, T. Urban Regeneration: Delivering Social Sustainability. In Urban Regeneration E Social Sustainability: Best Practice from European Cities; Wiley-Blackwell: Oxford, UK, 2011; pp. 54-79.

20. Martins, M.L.R.; dos Santos Pereira, A.L. Urban Regeneration in the Brazilian urban policy agenda. Eur. Plan. Stud. 2019, 27, 1129-1145. [CrossRef]

21. Chahardowli, M.; Sajadzadeh, H.; Aram, F.; Mosavi, A. Survey of sustainable regeneration of historic and cultural cores of cities. Energies 2020, 13, 2708. [CrossRef]

22. Alpopi, C.; Manole, C. Integrated Urban Regeneration-Solution for Cities Revitalize. Procedia Econ. Financ. 2013, 6, 178-185. [CrossRef]

23. Keresztély, K.; Scott, J.W. Urban Regeneration in the Post-Socialist Context: Budapest and the Search for a Social Dimension. Eur. Plan. Stud. 2012, 20, 1111-1134. [CrossRef]

24. Wittmayer, J.M.; van Steenbergen, F.; Rok, A.; Roorda, C. Governing sustainability: A dialogue between Local Agenda 21 and transition management. Local Environ. 2016, 21, 939-955. [CrossRef]

25. Caldas, P.; Ferreira, D.C.; Dollery, B.; Marques, R.C. Municipal sustainability influence by european union investment programs on the portuguese local government. Sustainability 2018, 10, 910. [CrossRef]

26. Navarro-Galera, A.; Alcaraz-Quiles, F.J.; Ortiz-Rodriguez, D. Enhancing sustainability transparency in local governments-An empirical research in Europe. Sustainability 2018, 10, 2161. [CrossRef]

27. Hambleton, R. Leading the Inclusive City: Place-Based Innovation for a Bounded Planet; Policy Press: Bristol, UK, 2015.

28. Akotia, J.; Sackey, E. Understanding socio-economic sustainability drivers of sustainable regeneration: An empirical study of regeneration practitioners in UK. Eur. Plan. Stud. 2018, 26, 2078-2098. [CrossRef]

29. Dempsey, N.; Bramley, G.; Power, S.; Brown, C. The social dimension of sustainable development: Defining urban social sustainability. Sustain. Dev. 2011, 19, 289-300. [CrossRef]

30. Glasson, J.; Wood, G. Urban regeneration and impact assessment for social sustainability. Impact Assess. Proj. Apprais. 2009, 27, 283-290. [CrossRef]

31. Mcdonald, S.; Malys, N.; Maliene, V.; Malienè, V. Urban regeneration for sustainable communities: A case study. Technol. Econ. Dev. Econ. Balt. J. Sustain. 2009, 15, 49-59. [CrossRef]

32. Murphy, K. The social pillar of sustainable development: A literature review and framework for policy analysis. Sustain. Sci. Pract. Policy 2012, 8, 15-29. [CrossRef]

33. Kim, J.; Larsen, K. Can new urbanism infill development contribute to social sustainability? The case of Orlando, Florida. Urban Stud. 2017, 54, 3843-3862. [CrossRef]

34. Meerow, S.; Pajouhesh, P.; Miller, T.R. Social equity in urban resilience planning. Local Environ. 2019, 24, 793-808. [CrossRef]

35. Xiao, Y.; Wang, Z.; Li, Z.; Tang, Z. An assessment of urban park access in Shanghai-Implications for the social equity in urban China. Landsc. Urban Plan. 2017, 157, 383-393. [CrossRef]

36. Bramley, G.; Power, S. Urban form and social sustainability: The role of density and housing type. Environ. Plan. B Plan. Des. 2009, 36, 30-48. [CrossRef]

37. Arundel, R.; Ronald, R. The role of urban form in sustainability of community: The case of Amsterdam. Environ. Plan. B Urban Anal. City Sci. 2017, 44, 33-53. [CrossRef]

38. Rashidfarokhi, A.; Yrjänä, L.; Wallenius, M.; Toivonen, S.; Ekroos, A.; Viitanen, K. Social sustainability tool for assessing land use planning processes. Eur. Plan. Stud. 2018, 26, 1269-1296. [CrossRef]

39. Colantonio, A.; Dixon, T.; Ganser, R.; Carpenter, J.; Ngombe, A. 'Creating Sustainable Environments' Measuring Socially Sustainable Urban Regeneration in Europe. 2009. Available online: http://oisd.brookes.ac.uk/sustainable_communities/ resources/Social_Sustainability_and_Urban_Regeneration_report.pdf (accessed on 28 May 2021).

40. Colantonio, A. Measuring Social Sustainability: Best Practice from Urban Renewal in the EU 2008/02: EIBURS Working Paper Series Traditional and Emerging Prospects in Social Sustainability. 2008. Available online: https:/ www.semanticscholar.org/paper/ Measuring-Social-Sustainability\%3A-Best-Practice-from-Colantonio/f755c9a8d879a7862bba63fb38f6712eb4391677 (accessed on 28 February 2021). 
41. Trivellato, B. How can 'smart' also be socially sustainable? Insights from the case of Milan. Eur. Urban Reg. Stud. 2017, 24, 337-351. [CrossRef]

42. Solly, A. Land use challenges, sustainability and the spatial planning balancing act: Insights from Sweden and Switzerland. Eur. Plan. Stud. 2021, 29, 637-653. [CrossRef]

43. Stawasz, D.; Sikora-Fernandez, D. Koncepcja Smart City na tle Procesów i Uwarunkowań Rozwoju Wspótczesnych Miast; Wydawnictwo Uniwersytetu Łódzkiego: Łódź, Poland, 2016.

44. Urząd Mieszkalnictwa i Rozwoju Miast and GTZ Gesellschaft für Technische Zusammenarbeit, "Podręcznik Rewitalizacji. Zasady, Procedury i Mechanizmy Działania Współczesnych Procesów Rewitalizacji. Warszawa. 2003. Available online: https: / /1lib.pl/book/1169022/25a54b?id=1169022\&secret=25a54b (accessed on 23 March 2021).

45. Sagan, I.; Grabkowska, M. Urban Regeneration in Gdańsk, Poland: Local Regimes and Tensions Between Top-Down Strategies and Endogenous Renewal. Eur. Plan. Stud. 2012, 20, 1135-1154. [CrossRef]

46. Gorczyca, K.; Kocaj, A.; Fiedeń, Ł. Large housing estates in Poland-A missing link in urban regeneration? Eur. Plan. Stud. 2020, 28, 2020-2039. [CrossRef]

47. Ciesiółka, P.; Kudłak, R.; Kołsut, B. Działania rewitalizacyjne w miastach województwa wielkopolskiego w latach 1999-2015 oraz ich efekty. Studia Regionalne i Lokalne 2016, 68, 50-68.

48. Stryjakiewicz, T.; Kudłak, R.; Ciesiółka, P.; Kołsut, B.; Motek, P. Urban regeneration in Poland's non-core regions. Eur. Plan. Stud. 2018, 26, 316-341. [CrossRef]

49. Uchwała nr 123 Rady Ministrów z Dnia 15 Października 2019 r. w Sprawie Przyjęcia ‘Strategii Zrównoważonego Rozwoju Wsi, Rolnictwa i Rybactwa 2030. Available online: http:/ / isap.sejm.gov.pl/isap.nsf/DocDetails.xsp?id=WMP20190001150 (accessed on 21 June 2021).

50. Ministry of Infrastructure and Development. Krajowa Polityka Miejska 2023. Warszawa. 2015. Available online: https: / / www.gov.pl/web / fundusze-regiony / polityka-miejska (accessed on 9 May 2021).

51. Ng, M.K. Quality of Life Perceptions and Directions for Urban Regeneration in Hong Kong; Springer: Berlin/Heidelberg, Germany, 2005; pp. 441-465.

52. Hambleton, R. Leading the healthy city: Taking advantage of the power of place. Cities Health 2020, 4, 221-228. [CrossRef]

53. Noworól, A.; Noworól, K. Rewitalizacja obszarów miejskich jako wehikuł rozwoju lokalnego. Stud. Kom. Przestrz. Zagospod. Kraju 2017, 17, 129-144.

54. Parysek, J. Rewitalizacja jako problem i zadanie własne polskich samorządów lokalnych. Rozw. Reg. Polityka Reg. 2016, 33, 17-36.

55. Natividade-Jesus, E.; Almeida, A.; Sousa, N.; Coutinho-Rodrigues, J. A Case Study Driven Integrated Methodology to Support Sustainable Urban Regeneration Planning and Management. Sustainability 2019, 11, 4129. [CrossRef]

56. Kowalska, M.; Szemik, S. Zdrowie i jakość życia a aktywność zawodowa. Med. Pr. 2016, 67, 663-671. [CrossRef] [PubMed]

57. Kearns, A.; Ghosh, S.; Mason, P.; Egan, M. Urban regeneration and mental health: Investigating the effects of an area-based intervention using a modified intention to treat analysis with alternative outcome measures. Health Place 2020, 61, 102262 [CrossRef]

58. McCartney, G.; Hearty, W.; Taulbut, M.; Mitchell, R.; Dryden, R.; Collins, C. Regeneration and health: A structured, rapid literature review. Public Health 2017, 148, 69-87. [CrossRef]

59. Pérez, M.G.R.; Laprise, M.; Rey, E. Fostering sustainable urban renewal at the neighborhood scale with a spatial decision support system. Sustain. Cities Soc. 2018, 38, 440-451. [CrossRef]

60. Huang, L.; Zheng, W.; Hong, J.; Liu, Y.; Liu, G. Paths and strategies for sustainable urban renewal at the neighbourhood level: A framework for decision-making. Sustain. Cities Soc. 2020, 55, 102074. [CrossRef]

61. Eizenberg, E.; Jabareen, Y. Social sustainability: A new conceptual framework. Sustainability 2017, 9, 68. [CrossRef]

62. Chan, H.H.; Hu, T.S.; Fan, P. Social sustainability of urban regeneration led by industrial land redevelopment in Taiwan. Eur. Plan. Stud. 2019, 27, 1245-1269. [CrossRef]

63. Turcu, C. Local experiences of urban sustainability: Researching Housing Market Renewal interventions in three English neighbourhoods. Prog. Plan. 2012, 78, 101-150. [CrossRef]

64. Weingaertner, C.; Barber, A.R.G. Urban regeneration and socio-economic sustainability: A role for established small food outlets. Eur. Plan. Stud. 2010, 18, 1653-1674. [CrossRef]

65. McGregor, A.; McConnachie, M. Social Exclusion, Urban Regeneration and Economic Reintegration. Urban Stud. 1995, 32, 1587-1600. [CrossRef]

66. Nguipdop-Djomo, P.; Rodrigues, L.C.; Abubakar, I.; Mangtani, P. Small-area level socio-economic deprivation and tuberculosis rates in England: An ecological analysis of tuberculosis notifications between 2008 and 2012. PLoS ONE 2020, 15, e0240879. [CrossRef] [PubMed]

67. Swinburn, G.; Goga, S.; Murphy, F. Local Economic Development: A Primer Developing and Implementing Local Economic Development Strategies and Action Plans; The World Bank: Washington, DC, USA, 2006; p. 33769.

68. Lupton, R.; Hughes, C.; Macdougall, A.; Simpkins, H.G.; Hjelmskog, A. Inclusive Growth in Greater Manchester 2020 and beyond: Taking Stock and Looking forward; University of Manchester: Manchester, UK, 2019.

69. Boyle, M.; Silver, I. Poverty, Partnerships, and Privilege: Elite Institutions and Community Empowerment. City Community 2005, 4, 233-253. [CrossRef]

70. Herbst, K. Społeczny sens rewitalizacji. Ekonomia Społeczna Teksty 2008, 3, 1-26. 
71. Wojnarowska, A.; Kozłowski, S. Rewitalizacja Zdegradowanych Obszarów Miejskich. Zagadnienia Teoretyczne; Wydawnictwo Uniwersytetu Łódzkiego: Łódź, Poland, 2011.

72. Dembicka-Niemiec, A.; Drobniak, A.; Szafranek, E. Wpływ projektów rewitalizacyjnych na konkurencyjność gospodarczą na przykładzie gmin województwa opolskiego. Probl. Rozw. Miast 2016, 4, 75-84.

73. Jadach-Sepioło, A. Rafy procesu rewitalizacji-teoria i polskie doświadczenia. Gospod. Prakt. Teor. 2017, 49, 23-39. [CrossRef]

74. GUS. Dane Statystyczne z Zakresu Rewitalizacji na Poziomie Gmin; GUS: Warszawa, Poland, 2018.

75. Jarczewski, W.; Kułaczkowska, A. Raport o Stanie Polskich Miast. Rewitalizacja; Instytut Rozwoju Miast i Regionów: WarszawaKraków, Poland, 2019.

76. Institute for Urban and Regional Development and Ecorys. Badanie Systemu Zarządzania i Wdrażania Procesów Rewitalizacji w Polsce-Ministerstwo Funduszy i Polityki Regionalnej. 2020. Available online: https://www.ewaluacja.gov.pl/ strony/badania-i-analizy / wyniki-badan-ewaluacyjnych/badania-ewaluacyjne/badanie-systemu-zarzadzania-i-wdrazaniaprocesow-rewitalizacji-w-polsce/ (accessed on 13 November 2020).

77. Brańka, P. Obszary wiejskie w woj. małopolskim o najwyższej koncentracji problemów społeczno-gospodarczych—identyfikacja, czynniki sprawcze-Studia KPZK-PAS Journals Repository. J. PAN 2017, 174. [CrossRef]

78. Jeżyńska, B. Partnerstwo wiejsko-miejskie jako koncepcja zrównoważonego rozwoju obszarów wiejskich. Teka Kom. Praw.-OL PAN 2018, 1, 73-86.

79. Kożuch, A. Rewitalizacja a zrównoważony rozwój obszarów wiejskich. Zarzadzanie Publiczne Zeszyty Naukowe Instytutu Spraw Publicznych Uniwersytetu Jagiellońskiego 2010, 1-2, 77-90.

80. Czupich, M. Level of Social Participation in the Creation of Urban Regeneration Programmes-The Case Study of Small Towns in Poland. Eur. Spat. Res. Policy 2018, 25, 81-98. [CrossRef]

81. Setkowicz, P. Kryzys zaufania. Partycypacja społeczna i podsycanie konfliktów w procesie kształtowania środowiska miejskiego na przykładzie Krakowa. Przestrz. Urban Archit. 2017, 2, 341-352. [CrossRef]

82. Hołuj, D.; Legutko-Kobus, P. A participatory model of creating revitalisation programmes in Poland-Challenges and barriers. Maz. Stud. Reg. 2018, 26, 33-59.

83. Masierek, E. Aktualne wyzwania rewitalizacyjne polskich miastna tle ich dotychczasowych doświadczeń. Probl. Rozw. Miast Kwartalnik Nauk. Inst. Rozw. Miast 2016, XIII, 19-29.

84. Parysek, J.J. Rewitalizacja miast w Polsce: Wczoraj, dziś i być może jutro. Stud. Miej. 2015, 17, 9-25.

85. Ciesiółka, P. Rewitalizacja w polityce rozwoju kraju. Rozw. Regionalny Polityka Regionalna 2017, 39, 9-28.

86. Dorota, B. Rewitalizacja jako obszar współpracy międzysektorowej. Rocz. Lubuski 2017, 43, 112-125.

87. Leszkowicz-Baczyński, J. Ewolucja Działań Rewitalizacyjnych w Polsce. Przegląd Problematyki. Rocz. Lubuski 2019, 45, 85-103.

88. Kwiatkowski, M. Rewitalizacja a spójność lokalna. Rola ekonomii społecznej. Stud. Reg. Lokal. 2021, 22, 60-83. 